\title{
Strategy Development of Community Base Tourism in Tidung Island, Jakarta
}

\author{
Muhamad Syahiddin; Dhian Tyas Untari*; Paryono Paryono \\ University of Indraprasta PGRI, South Jakarta, Indonesia \\ Email: tyas_un@yahoo.co.id
}

http://dx.doi.org/10.18415/ijmmu.v5i4.159

\begin{abstract}
The aim of thus study is to establish a community-based tourism development strategy in Tidung Island. Researcher use Strategy Management matrix, In this research, tourist entrepreneurs and tourist as an observation unit and is determined as an analysis unit of the company that is the decision makers are very influential in the company itself, including related Human Resources, Finance, Production, and Marketing. Eigen Factor score is use ase the weighting input data from the results of questionnaires. From the questionnaire, a score is obtained from the average given by the respondents at each key success factors, where in the input process the researcher used IFAS / IFAS Matrix, and in the process of strategy formulation, the researcher used the recommendation from the Grand Matrix Strategy output. The results of the output recommendations, which will then be implemented in the development of community-based tourism on the Island of Tidung. Based on the Grand Matrix Strategy chart is seen that the outline of Tidung Island tourism into the weak category, where the quadrant Challenges and Weaknesses is much greater than the strength and opportunities. Thus the strategy that can be done is with; improve tourism governance by maximizing the function of tourism development programs of DKI Jakarta Province, encouraging the Provincial Government of DKI Jakarta to allocate funds and attention to alternative tourism such as marine tourism located in Kepulauan Seribu, maximizing Community Service Activities of Higher Education as a medium of knowladge community transfer Pulau Tidung, improving the mode of transportation and increasing the frequency of ship felling Jakarta - Pulau Tidung.
\end{abstract}

Keywords: Pulau Tidung; Community Based Tourism; Jakarta;

\section{Introduction}

The concept of sustainable development encourages the participation of local communities, both actively and passively, so that the development of the tourism sector is closely linked to sustainable development (Van Breugel., 2013). It is expected that through the development of tourism can increase participation and empower local communities. The GAP that occurs between the private sector and the local community is often boundary (Purnamasari., 2011), so that the local people in fact do not get the maximum positive impact (Dewi., 2013).

One concept that explains the role of community in tourism development is Community Based Tourism (CBT). Conceptually the principle of community-based tourism as an empowerment approach that involves and lays the community as an important player in the context of a new paradigm of development that is sustainable development (paradigm) community-based tourism is an opportunity to mobilize all the potential and dynamics of society, to balance the role of business actors large-scale tourism. Law Number 10 Year 2009 on Tourism mandates that one of the objectives of tourism activities is the effort to conserve nature, environment and resources based on the principles of preserving nature and the environment, empowering local people and ensuring integration between sectors, between regions, between centers and areas that constitute a systemic unit within the framework of regional 
autonomy as well as the integration of stakeholders. Thus the implementation of the concept of Community Base Tourism becomes the answer to minimize the negative impact of tourism activities.

One of the interesting tourist destinations in Jakarta is Tidung Island tourism which is administratively located in the Thousand Islands District Administration. In connection with the implementation of decentralization policy through Law No.23 of 2004, the authority of tourism policy is the authority of local government. The implementation of regional autonomy provides logical consequences for local governments to take care of their own households, and has full responsibility for improving the prosperity of their people through tourism development activities. Tourism sector becomes one of the leading sectors in the economic development direction of Thousand Islands Regency, through the development of tourism sector is expected to maximize the existing tourism potential and can move towards independence.

Referring to the importance of community-based tourism development as reflected in Law Number 10 Year 2009 on Tourism of the Republic of Indonesia, this study aims to build a model of community-based tourism development strategy in Tidung Island.

\section{Methodology}

In this research, tourist entrepreneurs and tourist wisatwan serve as an observation unit and is determined as an analysis unit of the company that is the decision makers are very influential in the company itself, including related Human Resources, Finance, Production, and Marketing. For weighting used input data from the results of questionnaires for weighting. From the questionnaire taken a value obtained from the average given respondents on each key success factor. After obtained the value, then to get the weight done the division between the value of total value of the overall value on each factor that is external and internal. For key success factor that is by identifying key factor of variable from internal vector either strength or weakness and external factor that is opportunity and threat becoming indicator of company condition and formulate into alternative strategies.

To formulatate the strategy, researcher use matrix of Management Strategy. Where in the input process the researcher uses IFAS / IFAS Matrix, then in the process of strategy formation, researcher uses recommendation from Grand Matrix Strategy output. From the results of the output recommendations, which will then be implemented in the development of community-based tourism on the Island of Tidung.

\section{Results and Discussion}

Economic Impact of Tourism Activities for the People of Tidung Island tourism activities that have developed in Tidung Island is currently a type of community base tourism development where tourism management is fully handled by local communities. The tourism facilities provided by the community are; home stay, consumption (package) and food stall sellers, bicycle rental, snorkeling equipment, boats, fishing rods, banana boats, bicycle parking and tour guide services (Table 1). Tours on Pulau Tidung are sold with package models, where each type of package will be tailored to the type of tourist facilities obtained by tourists. Visitors to Tidung Island experience a significant increase on national and week end holidays, where at this time visitors look crowded certain sites.

\begin{tabular}{|c|c|c|c|}
\hline No & Tourist Facility & $\begin{array}{l}\text { Average earnings on weekday (per- } \\
\text { manager) in IDR }\end{array}$ & $\begin{array}{l}\text { Average earnings on weekend and national holidays } \\
\text { (per-manager) in Rp }\end{array}$ \\
\hline 1 & Home stay & 75.000 & 300.000 \\
\hline 2 & Food packages & 60.000 & 240.000 \\
\hline 3 & Restourant & 50.000 & 400.000 \\
\hline 4 & Bicycle rental & 40.000 & 200.000 \\
\hline 5 & Snorkling rental & 50.000 & 300.000 \\
\hline 6 & Boat & 150.000 & 250.000 \\
\hline 7 & fishing equipment & 10.000 & 100.000 \\
\hline 8 & Banana boat & 100.000 & 1.000 .000 \\
\hline 9 & Bicycle parking & 50.000 & 400.000 \\
\hline 10 & Tour guide & 100.000 & 400.000 \\
\hline 11 & Under water camera & 75.000 & 150.000 \\
\hline
\end{tabular}


Based on the results of the study shows that in general the price of units at tourist facilities in Tidung Island is quite cheap can be seen from the income of the community on weekdays; averaged by the number of facilities used on a typical day. And during the national holiday on Saturday, the number of wisatwan will increase significantly, then the income of the society will increase.

\section{Model Analysis of Community Base Tourism Development Strategy in Tidung Island}

Based on the results of the study then got some key factor which will then be processed into a grand model of strategy development of community base tourism in Tidung Island. The key factor will be divided into two broad categories namely Internal Factors (strengths and weaknesses) and External Factors (threats and challenges). Then both categories will be given weight and rank in accordance with empirical data obtained by researchers at the time of doing research, based on Table 2.

The result of EFAS/ IFAS matrix is then inputted into Grand Strategy Matrix, base of Figure1, to get a picture of tourism positioning in Pulau Tidung and get alternative strategy.

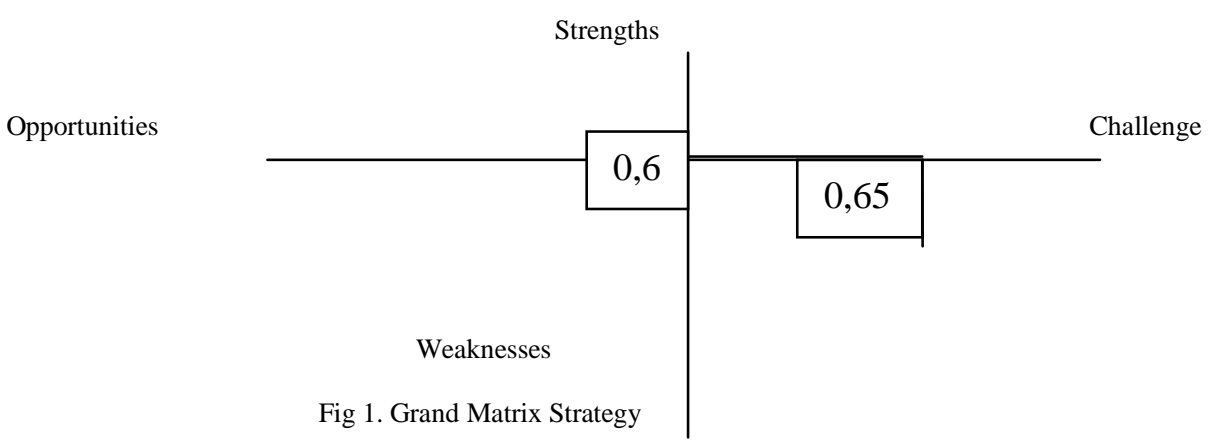

Table 2 EFAS/ IFAS Matrix

\begin{tabular}{|c|c|c|c|c|}
\hline No & Category & Weight & Rank & Total Ecore \\
\hline \multicolumn{5}{|c|}{ Internal Factor } \\
\hline \multicolumn{5}{|c|}{ Strengths } \\
\hline 1 & Low price & 0,40 & 3 & 1,2 \\
\hline 2 & Local people have a big economic impact & 0,30 & 2 & 0,6 \\
\hline \multirow[t]{2}{*}{3} & The Island is not too wide & 0,30 & 2 & 0,6 \\
\hline & & & & 2,4 \\
\hline \multicolumn{5}{|c|}{ Weakness } \\
\hline 1 & The governance is still very traditional & 0,35 & 4 & 1,4 \\
\hline 2 & $\begin{array}{l}\text { The management of the less-visited } \\
\text { tourist facilities }\end{array}$ & 0,45 & 4 & 1,8 \\
\hline \multirow[t]{2}{*}{3} & Do not have a special icon that reflects & 0,20 & 4 & 0,8 \\
\hline & & & & 30 \\
\hline \multicolumn{5}{|c|}{ External Factor } \\
\hline \multicolumn{5}{|c|}{ Opportunity } \\
\hline 1 & The location is not far from Jakarta & 0,25 & 3 & 0,75 \\
\hline 2 & The attention of the Jakarta Provincial & 0,45 & 3 & 1,35 \\
\hline & $\begin{array}{l}\text { Government is high on the development } \\
\text { of tourism }\end{array}$ & & & \\
\hline \multirow[t]{2}{*}{3} & A lot of hospitality training is provided & 0,30 & 2 & 0,60 \\
\hline & by the universities in Jakarta & & & 270 \\
\hline \multicolumn{5}{|c|}{ Treat } \\
\hline 1 & The ship becomes the only mode of & 0,35 & 3 & 1,05 \\
\hline & transportation, so the tour on Tidung & & & \\
\hline & Island is highly dependent by the season & & & \\
\hline 2 & Many Islands in the Thousand Islands are & 0,35 & 4 & 1,40 \\
\hline & managed by the private sector with better & & & \\
\hline & governance & & & \\
\hline \multirow[t]{2}{*}{3} & Visitors to Tidung Island are the first & 0,30 & 3 & 0,90 \\
\hline & & & & 3,35 \\
\hline
\end{tabular}


Based on the Grand Matrix Strategy chart in Figure 1, is seen that the outline of Tidung Island tourism into the weak category, where the quadrant Challenges and Weaknesses is much greater than the strength and opportunities. Thus the strategy that can be done is with;

1. Improve tourism governance by maximizing the function of tourism development programs of DKI Jakarta Province

2. Encourage the Provincial Government of DKI Jakarta to allocate funds and attention to alternative tourism such as marine tourism located in Kepulauan Seribu.

3. Maximizing the Community Service Activities of Higher Education as a medium of transfer knowladge Tidung Island community

4. Improve the mode of transportation

5. Increasing the frequency of felling vessels Jakarta - Pulau Tidung

\section{Conclusion}

Tidung Island merpakan one region that has considerable tourism potential. Currently the demand for tourism in Pulau Tidung is quite high, and the community has enough positive impact from tourism development in Tidung Island. It's just that the problems arise when tourism governance Tidung Island is currently still done in a very simple way, the fact that appears is the tourists who come have no desire to return to Tidung Island tour, feared at one particular point Tidung Island tour will experience saturation and will greatly impacting people's incomes. To anticipate such matters, the Government, Academics, Private Parties and Local Communities must work together to provide more value on Tidung Island tourism by improving the tourism governance system. So the sustainability of Tidung Island tour will be more secure.

\section{References}

Aminuddin, M. N., Bahruddin, M., \& Yosep, S. P. (2015). Penciptaan Buku Esai Fotografi Pantai Jatimalang Untuk Mengoptimalkan Potensi Wisata Purworejo. Jurnal ArtNouveau, 4(1): 105-117.

Dewi, M. H. U. (2013). Pengembangan Desa Wisata Berbasis Partisipasi Masyarakat Lokal di Desa Wisata Jatiluwih Tabanan, Bali. Jurnal Kawistara, 3(2). Retrieved from https://journal.ugm.ac.id/ kawistara/article/view/3976.

Dewi, Ike Juwita. (2011). Implementasi dan Implikasi Kelembagaan Pemasaana Pariwisata yang Bertanggujawab (Responsible Tourism Marketing). Kementrian Kebudayaan dan Pariwisata Republik Indonesia.

Dinas, K. (2015). Statistik Kepariwisataan 2014. Daerah Istimewa Jokjakarta: Dinas Pariwisata DIY.

Kreag, G. (2001). TheImpacts of Tourism (Sharon Moen). Minnesota Sea Grant. Retrieved from https://pdfs.semanticscholar.org/f79c/c8bf257c28d986054878ae9045c5b63e7237.pdf.

Nordin, A. O. S., Lonik, K. A. T., \& Jaafar, M. (2014). Empowering Local Communities through Tourism Entrepreneurship: The Case of Micro Tourism Entrepreneurs in Langkawi Island. In SHS Web 
of Conferences (Vol. 12, p. 01101). EDP Sciences. Retrieved from http://www.shsconferences.org/ articles/shsconf/abs/2014/09/shsconf_4ictr2014_01101/shsconf_4ictr2014_01101.html.

Purnamasari, A. M. (2011). Pengembangan Masyarakat Untuk Pariwisata Di Kampung Wisata Toddabojo Provinsi Sulawesi Selatan. Jurnal Perencanaan Wilayah Dan Kota, 22(1): 49-64.

Tsundoda, T., Mendlinger, S., \& others. (2009). Economic and social impact of tourism on a small town: Peterborough New Hampshire. Journal of Service Science and Management, 2(02): 61.

Van Breugel, L. (2013). Community-based tourism: Local participation and perceived impacts. Retrieved from http://www.ru.nl/publish/pages/757346/thesis_liedewij_van_breugel_scs.pdf.

Zaei, M. E., \& Zaei, M. E. (2013). The impacts of tourism industry on host community. European Journal of Tourism Hospitality and Research, 1(2): 12-21.

\section{Copyrights}

Copyright for this article is retained by the author(s), with first publication rights granted to the journal. This is an open-access article distributed under the terms and conditions of the Creative Commons Attribution license (http://creativecommons.org/licenses/by/4.0/). 